\title{
Management of Soilborne Diseases in Strawberry Using Vegetable Rotations
}

\author{
K. V. Subbarao and Z. Kabir, Department of Plant Pathology, University of California, Davis, c/o United States \\ Agricultural Research Station, Salinas, CA 93905; F. N. Martin, United States Department of Agriculture- \\ Agricultural Research Service, Salinas, CA 93905; and S. T. Koike, University of California Cooperative Extension, \\ Salinas 93901
}

\begin{abstract}
Subbarao, K. V., Kabir, Z., Martin, F. N., and Koike, S. T. 2007. Management of soilborne diseases in strawberry using vegetable rotations. Plant Dis. 91:964-972.

The influence of crop rotation on soilborne diseases and yield of strawberry (Fragaria $x$ ananassa) was determined at a site infested with Verticillium dahliae microsclerotia and at another with no known history of V. dahliae infestation during 1997 to 2000. The rotations studied at the $V$. dahliae-infested site were (i) broccoli-broccoli-strawberry, (ii) Brussels sproutsstrawberry, and (iii) lettuce-lettuce-strawberry; the treatments at the site with no history of $V$. dahliae were (i) broccoli-broccoli-strawberry, (ii) cauliflower-cauliflower-strawberry, and (iii) lettuce-lettuce-strawberry. The effects of rotation on V. dahliae and Pythium populations, strawberry vigor, Verticillium wilt severity, and strawberry fruit yield were compared with a standard methyl bromide + chloropicrin fumigated control treatment at both sites. Rotations did not alter total population levels of Pythium spp. at either study site. However, V. dahliae microsclerotia were significantly reduced with broccoli and Brussels sprouts rotations compared with lettuce rotations at the $V$. dahliae-infested site. Reduced propagules led to lower Verticillium wilt severity on strawberry plants in the broccoli and Brussels sprouts rotations than in lettuce-rotated plots. Strawberry vigor and fruit yield were significantly lower in lettuce-rotated plots than in broccoli- and Brussels sprouts-rotated plots. Despite no detectable microsclerotia at the other site, strawberry vigor and fruit yield were greatest in plots rotated with broccoli, intermediate with cauliflower, and lowest with lettuce. None of the rotation treatments were better than the fumigated control for all variables measured. In the absence of fumigation, rotation with broccoli and Brussels sprouts is an effective cultural practice for managing Verticillium wilt in strawberry production; whereas, in fields with no detectable V. dahliae, broccoli is also a feasible rotational crop that enhances strawberry growth and yield. According to a cost-benefit analysis, the broccoli-strawberry rotation system could be an economically viable option provided growers are able to alternate years for strawberry cultivation.
\end{abstract}

Strawberry (Fragaria $\times$ ananassa Duchesne) production in California accounts for more than $80 \%$ of total U.S. production, with an annual farm gate value of $\$ 1.10$ billion (24), which is four times greater than all other states combined (37). In addition, California produces nearly one billion strawberry transplants each year in nurseries, and these transplants must meet strict phytosanitary standards for local production and export. Such a profitable industry in California has been made possible by the fumigation technology developed in the 1950s with methyl bromide and chloropicrin $(7,41,42)$. Since then, preplant fumigation with methyl bromide and chloropicrin has become an integral part of the California strawberry production industry (41), and nearly all conventional strawberry production occurs in

Corresponding author: K. V. Subbarao

E-mail:kvsubbarao@ucdavis.edu.

Accepted for publication 27 February 2007.

doi:10.1094/PDIS-91-8-0964

(C) 2007 The American Phytopathological Society fumigated soils $(1,41)$. Annual soil fumigation has contributed to the control of soilborne pathogens, nematodes, and weeds while also boosting the yields of strawberry plants. Historically, this also allowed breeding programs to focus on improving horticultural characteristics of strawberry cultivars in lieu of emphasizing disease resistance.

Because of the negative effects of methyl bromide on stratospheric ozone, the fumigant was designated as a class I stratospheric ozone depleting substance by the Montreal Protocol $(21,27)$ and as a significant risk to human health (23). The continued availability of this efficient fumigant for agricultural soil fumigation beyond the 2005 phase-out date will be through critical-use exemptions. It has been estimated that annual losses in shortterm net farm income in California will be more than $\$ 162$ million, with strawberry accounting for more than $60 \%$ of these losses $(8,9)$. Over the past 10 years, research has focused on identifying alternative fumigants with efficacy comparable with methyl bromide (14). Alternative fumigants such as chloropicrin and Telone C35 have been identified, and improved application techniques have been developed to reduce emissions $(1,14)$. Although chloropicrin is as efficacious as methyl bromide + chloropicrin at high rates, these are not feasible for the growers due to regulatory limits placed on application rates. Regardless, chemical alternatives to methyl bromide will be subjected to increasing review and regulation and they may not be readily available over the longer term. It has been estimated that soilborne diseases caused by Pythium, Phytophthora, Cylindrocarpon, Macrophomina, Rhizoctonia, and Verticillium spp. result in 20 to $30 \%$ strawberry yield losses in the absence of fumigation $(8,37)$. Therefore, longer-term research is required to develop nonchemical alternatives, and their adaptation will require effective integration with other methods of disease, pest, and crop management (13).

In the post-methyl bromide era, Verticillium wilt is likely to reemerge as a major disease for conventional strawberry production. The disease already is a major problem in some organic production fields. In strawberry, symptoms begin to appear during early to mid-season, with outer leaves on infected plants turning yellow, drooping, and later turning brown and dry. Yield from these affected plants can be dramatically reduced and infected plants usually die before the end of the season (40). The fungus survives in the soil as microsclerotia for many years, and survives better in sandy loam soils typical of strawberry production fields in coastal California than in other types of soil $(39,40)$. Large numbers of microsclerotia are formed in colonized tissue of susceptible crops, and a few are formed even on nonhosts $(35,36)$. Whether microsclerotia are formed on infected strawberry plants is not known.

Resistance to Verticillium wilt is unavailable in currently used commercial cultivars and tolerance in these cultivars is low. With the phase out of methyl bromide and possible future loss or restrictions on the use of alternative fumigants, resistance to Verticillium wilt has now become a selection criterion in some breeding programs. As a result, resistance to Verticillium wilt in locally adapted strawberry cultivars may increase over time.

The concept of rotating crops to manage plant diseases is perhaps one of the oldest cultural practices in agriculture (11). The 
utility of this practice in reducing Verticillium dahliae inoculum and subsequent disease intensity has been equivocal $(12,25)$. Microsclerotia of $V$. dahliae survive in the soil up to 10 years, and the extensive host range (including both crops and weeds) and lack of host specificity (26) reduce the usefulness of some crop rotations for Verticillium wilt management (15). However, recent work $(34,36,43)$ has shown that rotations with broccoli dramatically reduce microsclerotial numbers and Verticillium wilt incidence in susceptible crops. If rotations of broccoli are successful in strawberry, they will be equally applicable to both conventional and organic strawberry production systems. Although the benefits of rotations are numerous and quantification of these benefits in dollar terms is difficult, simple cost-benefit analysis of adapting rotations will inevitably lead to a better understanding of their composite benefits. Such information also may lead to increased adoption of crop rotations.

The objectives of this study were to determine the effect of crop rotation on soilborne fungal inoculum density, disease severity, and strawberry growth and yield; to assess the effectiveness of crop rotation in soil with no detectable Verticillium spp. to improve strawberry growth and yield; and to obtain a cost-benefit analysis of this method of managing Verticillium wilt in strawberry.

\section{MATERIALS AND METHODS}

Experimental sites. Experiments on vegetable-strawberry rotations were conducted at two sites from winter 1997 to fall 2000. One site was located at the United States Department of Agriculture, Agricultural Research Station at Salinas, CA (latitude $36^{\circ} 4^{\prime} \mathrm{N}$, longitude $121^{\circ} 3^{\prime} \mathrm{W}$ elevation approximately $36 \mathrm{~m}$ ) with no history of either strawberry cultivation or Verticillium wilt (and no detectable Verticillium spp.); however, the site had other soilborne pathogens such as Pythium spp., Rhizoctonia solani, binucleate Rhizoctonia, and Cylindrocarpon spp. The other site was located at the Monterey Bay Academy in Watsonville, CA (latitude $36^{\circ} 5^{\prime} \mathrm{N}$, longitude $121^{\circ} 5^{\prime} \mathrm{W}$, elevation $64.45 \mathrm{~m}$ ) and has a history of strawberry production and disease pressure from $V$. dahliae as well as the above-noted root rot pathogens. Both sites lie in the major strawberry production areas of the central coast of California and prior investigations confirmed that black root rot pathogens were present and causing disease (20). Soil at the Salinas site was a Chualar loam (fine-loamy, mixed thermic, Typic Argixeroll) with 57\% sand, $31 \%$ silt, $1.1 \%$ organic matter, and a $\mathrm{pH}$ of 5.6. Soil at the Watsonville site was an Elder sandy loam (coarse-loamy, mixed, thermic, Cumulic Haploxeroll) with $62 \%$ sand, $26 \%$ silt, $0.6 \%$ organic matter, and a $\mathrm{pH}$ of 6.1 . Average yearly precipitation at
Salinas and Watsonville was 429 and 757 $\mathrm{mm}$, respectively, and mean daily temperature ranged from 8.3 to $19.9^{\circ} \mathrm{C}$ (minimum to maximum) and 8.3 to $19.7^{\circ} \mathrm{C}$ (minimum to maximum), respectively, during the study. The experimental design was a randomized complete block design with four replications. At both locations, two crops per year of vegetables (except for Brussels sprouts, which was grown only once a year because of its extended crop duration) were grown followed by rotation with annual strawberry.

Rotation treatments. There were three rotation treatments at each location in 1997 and 1999. The crop sequences were (i) broccoli-broccoli-strawberry, (ii) lettucelettuce-strawberry and (iii) Brussels sprouts-strawberry (Watsonville) or cauliflower-cauliflower-strawberry (Salinas). The first cycle of vegetables, including broccoli (cv. Marathon) (Brassica oleracea L. var. italica), cauliflower (cv. Apex) (B. oleracea var. botrytis L.) (Salinas only), Brussels sprouts (cv. Oliver) (B. oleracea L. var. gemmifera) (Watsonville only), and lettuce (cv. Salinas) (Lactuca sativa L.), was grown in January or February and harvested in June in each year. The second cycle of vegetables (excluding Brussels sprouts at the Watsonville site) was planted in July and harvested in September or October. Because of varying maturity times, planting dates were staggered so that all crops could be harvested and incorporated at the same time. Each treatment replication was separated by $2 \mathrm{~m}$ of bare soil to reduce plot interactions. At the Watsonville site, the individual plots consisted of two beds of $7.6 \mathrm{~m}$ in length with a single plant line for Brussels sprouts and two seed lines on the 1-m-wide beds standard for lettuce and broccoli production in coastal California. Plant spacing was approximately $30 \mathrm{~cm}$ between plant lines and $20 \mathrm{~cm}$ between plants within a plant line for lettuce and Brussels sprouts and $10 \mathrm{~cm}$ between plants for broccoli. At the Salinas site, the individual plots were $9 \mathrm{~m}$ long and eight 1-m beds wide and consisted of two plant lines for lettuce and broccoli production in coastal California. The beds contained a single plant line for cauliflower. Plant spacing was approximately $30 \mathrm{~cm}$ between plant lines and $30 \mathrm{~cm}$ between plants within a plant line for lettuce and cauliflower. Plant spacing was $15 \mathrm{~cm}$ between plants for broccoli. In both years, 4to 5-week-old transplants of broccoli, cauliflower, Brussels sprouts, and lettuce were planted. At the Salinas site, however, lettuce was direct seeded in two rows per bed and thinned to a spacing of $30 \mathrm{~cm} 3$ weeks after emergence. After transplanting, the experimental sites were irrigated with sprinklers for 3 to 4 days to ensure proper establishment of plants. The rotational vegetable planting cycles were timed to include two rotational crops of broccoli, cauliflower, or lettuce per year and one
Brussels sprouts crop. All experiments were maintained using standard cultural practices for coastal California vegetable production. Preplant fertilizer at $450 \mathrm{~kg}$ $\mathrm{ha}^{-1}(15 \mathrm{~N}-15 \mathrm{P}-15 \mathrm{~K})$ was applied to all beds before transplanting or direct seeding, and all plots were drip-irrigated twice a week. Two side dressings at $67 \mathrm{~kg} \mathrm{ha}^{-1}$ $(15 \mathrm{~N}-15 \mathrm{P}-15 \mathrm{~K})$ followed by fertigation at the rate of 11 to $22 \mathrm{~kg} \mathrm{ha}^{-1}$ (15N-0P-0K) were provided during each season. At maturity, all marketable vegetables were harvested and remaining residues were flail shredded, air dried on the soil surface for $48 \mathrm{~h}$, and incorporated into the soil to a depth of 15 to $20 \mathrm{~cm}$ using a rototiller. Three to four weeks after incorporation, the beds in all plots were reworked for the next vegetable or strawberry production cycle. The second crops of vegetables were grown and incorporated similarly.

Strawberry production. Standard cultural practices for strawberry production were followed for bed preparation (7). Beds in the control plots were fumigated with methyl bromide plus chloropicrin (67 and $33 \%$, respectively) at the rate of 450 $\mathrm{kg} \mathrm{ha}^{-1}$. Fumigants were injected at a depth of 15 to $25 \mathrm{~cm}$ through two hollow shanks, and black or brown high-density polyethylene $(35.6 \mu \mathrm{m}$ thick) tarps were used to cover the soil immediately after application. Vegetable rotation plots also were covered with black or brown high-density polyethylene tarps before planting strawberry. Two weeks after fumigation, slowrelease fertilizer $(18 \mathrm{~N}-8 \mathrm{P}-13 \mathrm{~K})$ was applied at the rate of $672 \mathrm{~kg} \mathrm{ha}^{-1}$ at both sites to all treatments. Fertilizer was bandplaced about 10 to $15 \mathrm{~cm}$ deep in each planting row and covered with approximately $4 \mathrm{~cm}$ soil to prevent direct contact with plant roots. Bare-root transplants of strawberry cv. Selva were planted $15 \mathrm{~cm}$ apart in all plots at both locations in two rows per bed spaced $40 \mathrm{~cm}$ apart in midNovember of 1997-98 and 1999-2000 (plot sizes for strawberry crop were two beds of $7.6 \mathrm{~m}$ at Watsonville and six beds of $9 \mathrm{~m}$ at the Salinas site). The drip irrigation system consisted of two drip tapes (Netafilm Streamline 60; Netafilm, Fresno, CA) with emitters spaced $30 \mathrm{~cm}$ apart, placed $8 \mathrm{~cm}$ from the bed center at a depth of 2 to $4 \mathrm{~cm}$, with an emitter flow rate of 0.87 liter $\mathrm{min}^{-1}$ at $70 \mathrm{kPa}$. Approximately $30 \mathrm{~mm}$ of water per week was applied to each of the experimental plots. After plants were established, drip irrigation was applied once or twice per week for 1.5 to $2 \mathrm{~h}$ depending on soil moisture conditions. Hand weeding was done periodically when necessary. All management and harvest of the strawberry crop was done by cooperating commercial growers.

Soil sampling and assay. To determine the densities of propagules of $V$. dahliae and Pythium spp., soil samples were collected at the beginning and end of the rotation crop and every month after the start of 
strawberry production. Soil samples (50 to $75 \mathrm{~g}$ ) were taken to a depth of 6 to $10 \mathrm{~cm}$ from 10 random sites in each treatment, in the center four beds at the Salinas site and in both beds at the Watsonville site. Samples from each treatment were bulked and placed in paper bags and air dried for 4 weeks on greenhouse benches. The dried soil then was assayed for $V$. dahliae propagules by direct plating onto improved NP-10 medium (16) using the modified Anderson sampler technique (6). After 3 weeks of incubation in the dark, the plates were washed in a gentle stream of water and examined under a stereoscope $(\times 10)$. The number of microsclerotial colonies on each plate was counted and expressed as microsclerotia per gram of dry soil.

For the determination of the number of CFU of Pythium spp., $1 \mathrm{~g}$ of air-dried soil was added to $10-\mathrm{ml}$ sterilized water blanks (triplicate tubes for each sample) and vortexed to mix the soil, and $500 \mu$ of this soil solution was distributed evenly over a petri dish containing a semiselective Pythium medium (five plates per tube). The medium consisted of corn meal agar (17 g liter $^{-1}$; BBL, Kansas City, MO) amended immediately after autoclaving with $0.1 \%$ Tween 20 followed by pimaricin $(10 \mathrm{mg}$ liter $\left.{ }^{-1}\right)$, ampicillin (250 mg liter ${ }^{-1}$, rifampicin $\left(10 \mathrm{mg} \mathrm{liter}^{-1}\right)$, rose bengal $(50 \mathrm{mg}$ liter $^{-1}$ ), and Benomyl 50WP (20 mg liter ${ }^{-1}$; DuPont, Wilmington, DE) after the medium had cooled to $50^{\circ} \mathrm{C}$ (19). After $24 \mathrm{~h}$ of incubation at $25^{\circ} \mathrm{C}$, the surfaces of the plates were washed free of soil under a gentle stream of water and the number of colonies counted. Plates were placed back into the incubator and subsequent counts made again after $24 \mathrm{~h}$. The total colony counts were expressed as CFU g $\mathrm{g}^{-1}$ of dry soil and the presented data reflects the mean of the three replicates. Prior investigations at these sites revealed that Pythium ultimum was the most commonly encountered species, but other species such as $P$. irregulare were recovered as well (F. Martin, unpublished).

Plant vigor and disease assessment. To determine the relative effects of different rotation treatments, strawberry plant growth was monitored by recording the plant canopy diameter of 20 arbitrarily chosen plants per replication at least twice per season in each replication. Measurements were made in both the east-west and north-south directions because there were significant directional effects early in the season. Development of Verticillium wilt at Watsonville was assessed based on foliar symptoms (initial symptoms of a stunted plant, followed by a rosette of dead leaves and progressing on to a dead plant). The symptoms of root diseases such as black root rot complex were similar but rarely progressed past stunting with leaf chlorosis later in the season (F. Martin, unpublished). Assessments were made at 2-week intervals starting from June until the end of the season (August to September). No Verticillium wilt was observed at the Salinas site. Twenty plants per plot were visually rated to monitor disease progress. The disease severity estimate was made based on a scale of 1 to 8 , where $1=$

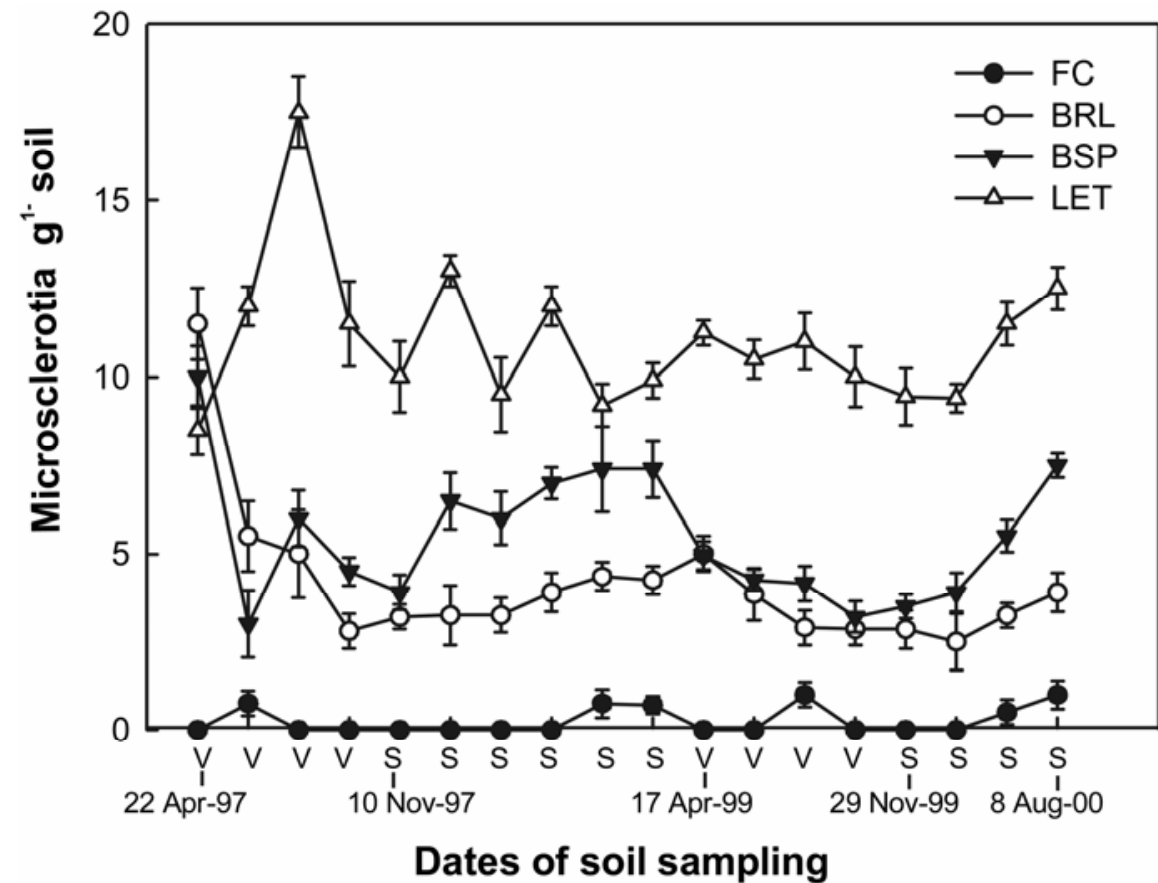

Fig. 1. Microsclerotia of Verticillium dahliae present in the soil at Watsonville during vegetablestrawberry rotation system from 1997 to 2000. Dates on X axis refer to the planting dates of either vegetables or strawberry. Abbreviations: $\mathrm{V}=$ vegetable rotation seasons, $\mathrm{S}=$ strawberry production seasons, $\mathrm{FC}=$ fumigated control, $\mathrm{BRL}=$ broccoli rotation plots, $\mathrm{BSP}=$ Brussels sprouts rotation plots, and LET $=$ lettuce rotation plots. Vertical bars represent the standard error of the mean. healthy plant, $2=$ moderately stunted, $3=$ moderately stunted and slight outer rosette of dead leaves, $4=$ moderately stunted and moderate outer rosette of dead leaves, $5=$ significantly stunted and slight outer rosette of dead leaves, $6=$ significantly stunted and moderate outer rosette of dead leaves, $7=$ significantly stunted and significant rosette of dead leaves, $8=$ dead plant.

Strawberry yield. In each plot, strawberry fruit were harvested weekly from the 20 marked plants in each treatment replication, sorted, and weighed as marketable and nonmarketable. Fruit yield data were collected from March to August or September in 1998 and 2000 and expressed as grams per plant.

Cost-benefit analysis. Data on the cost of production of strawberry fruit, including fumigating, preparing of land, mulching, planting, irrigating, fertigating, weeding, and fruit harvesting, were obtained from four growers that produce both strawberry and vegetables. Similarly, total yields per unit area of production, corresponding revenue earned, and so on also were obtained. Similar data were obtained for strawberry production without fumigation. The cost of producing two crops of broccoli, revenue from broccoli, and the following strawberry crop also was obtained. The data were expressed on a per-hectare basis, and cost-benefit estimates obtained for the following three scenarios: (i) growing strawberry with fumigation, (ii) growing strawberry without fumigation, and (iii) growing broccoli and strawberry sequentially.

Data analyses. The effects of treatments on plant canopy diameter, disease severity, and strawberry yield data were determined by analysis of variance (ANOVA) for each site separately, and means were compared by the least significant difference (LSD) test $(P \leq 0.05)$. Means and the corresponding standard errors of the mean were computed for each treatment and sampling time. Repeated measures ANOVA was used to determine treatment differences in microsclerotia in soil and disease severity on strawberry plants. All analyses were done using SAS (release 8.0 ed.; SAS Institute, Cary, NC).

\section{RESULTS}

Effects on resident microsclerotia. At the Watsonville site, soil inoculum levels of $V$. dahliae were moderate at the start of the experiment (Fig. 1) in 1997. The inoculum levels either increased or decreased depending on the vegetable rotations tested. Rotations with lettuce increased the number of microsclerotia in soil, with upper ranges of 10 to 17 microsclerotia $\mathrm{g}^{-1}$ of soil being most frequent. In contrast, rotations with Brussels sprouts significantly reduced microsclerotia of $V$. dahliae both in 1997 and 1999 relative to the pretreatment numbers (Fig. 1). Of the three 
rotations tested, the lowest number of $V$. dahliae microsclerotia was observed in plots rotated with broccoli. The reduction of $V$. dahliae microsclerotia at the end of two cycles of broccoli in 1997 was approximately $74 \%$. Following this dramatic reduction, cultivation of strawberry in these plots increased $V$. dahliae microsclerotia by $29 \%$ over pre-strawberry levels in 1997-98. However, a second cycle of broccoli rotations reduced the microsclerotia by $83 \%$ over the initial 1997 levels, followed by a $33 \%$ increase of microsclerotia over pre-strawberry levels at the end of the second strawberry crop. Rotations with Brussels sprouts reduced $V$. dahliae propagules by 55 and $65 \%$ in 1997 and 1999, respectively. However, following strawberry crops in these plots, V. dahliae microsclerotia increased by $87 \%$ in 199798 and by $93 \%$ in $1999-2000$. The fumigated control treatment had the lowest amount of inoculum (Fig. 1) among all treatments. No detectable microsclerotia of $V$. dahliae were present in the Salinas field soils during either vegetable or strawberry seasons.

Effects on Pythium propagules. At both locations, rotations had little influence on population levels of total Pythium spp. (data not shown). At the Watsonville site, populations ranged from 14 to 80 $\mathrm{CFU} \mathrm{g^{-1 }}$ of dry soil whereas, at the Salinas site, they ranged from 54 to $118 \mathrm{CFU} \mathrm{g}^{-1}$ of dry soil in 1997 and 190 to $440 \mathrm{CFU} \mathrm{g}^{-1}$ of dry soil in 1998. Differences in populations among treatments for the same year were not significant $(P=0.05)$ or related to cropping history. Although exact population counts were not made, the most commonly recovered species was $P$. ultimum.

Effects on strawberry growth. Strawberry plants grown in plots rotated with lettuce at both locations had a significantly $(P \leq 0.05)$ smaller canopy diameter than other rotation treatments. In Watsonville, broccoli- and Brussels sprouts-rotated plots and fumigated control plots, plants had a greater canopy diameter than strawberry plants in lettuce rotation plots (Fig. 2A). These differences were maintained until the vegetative phase of strawberry growth (Fig. 2A). In 2000, the canopy diameter of strawberry plants was higher in fumigated control and broccoli rotation plots than in the lettuce and Brussels
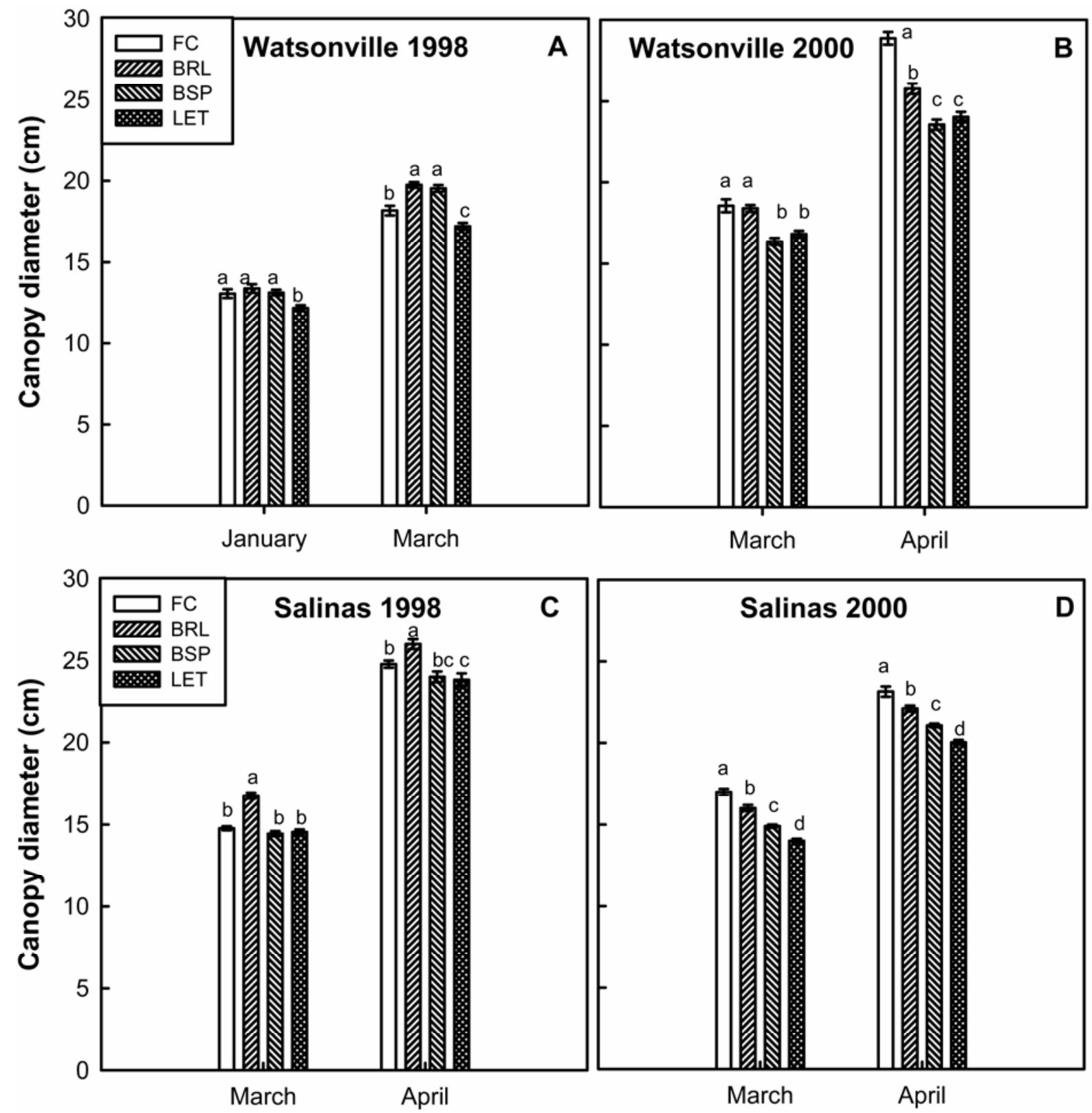

Fig. 2. Strawberry canopy diameter in A and C, 1998 and $\mathbf{B}$ and D, 2000 at Watsonville and Salinas, CA. Abbreviations: FC = fumigated control, BRL = broccoli rotation plots, $\mathrm{BSP}=$ Brussels sprouts rotation plots, $\mathrm{CAL}=$ cauliflower rotation plots, and LET $=$ lettuce rotation plots. Vertical bars represent the standard error of the mean. Different letters on the bars indicate significant differences among the treatments according to least significant difference at $P \leq$ 0.05 . 
sprouts rotation plots. Subsequently, however, the highest canopy diameter was observed in the fumigated control, followed by broccoli, Brussels sprouts, and lettuce rotation plots (Fig. 2B).

At the Salinas site in 1998, strawberry plants in broccoli-rotated plots had the highest canopy diameter, and the differences between fumigated control and other rotations were variable. Conditions during fumigation in 1998 were not optimal; typical robustness in these plots (Fig. 2C). In 2000, the response of strawberry canopy diameter to various rotation treatments was typical of what was observed at the Wathence, strawberry plants did not show the

sonville site, with the plants being more robust in the fumigated control followed by broccoli, cauliflower, and lettuce plants. There were significant differences between each of the treatments on both assessment dates (Fig. 2D).

Effect of rotations on disease severity. Repeated-measures ANOVA indicated that the rotation treatments significantly affected disease severity on strawberry for all observation dates at both locations. The highest wilt severity was observed in the lettuce rotation plots throughout the season in 1998 at the Watsonville site and the lowest was in the fumigated plots (Fig. $3 \mathrm{~A})$. Broccoli rotation plots had the lowest
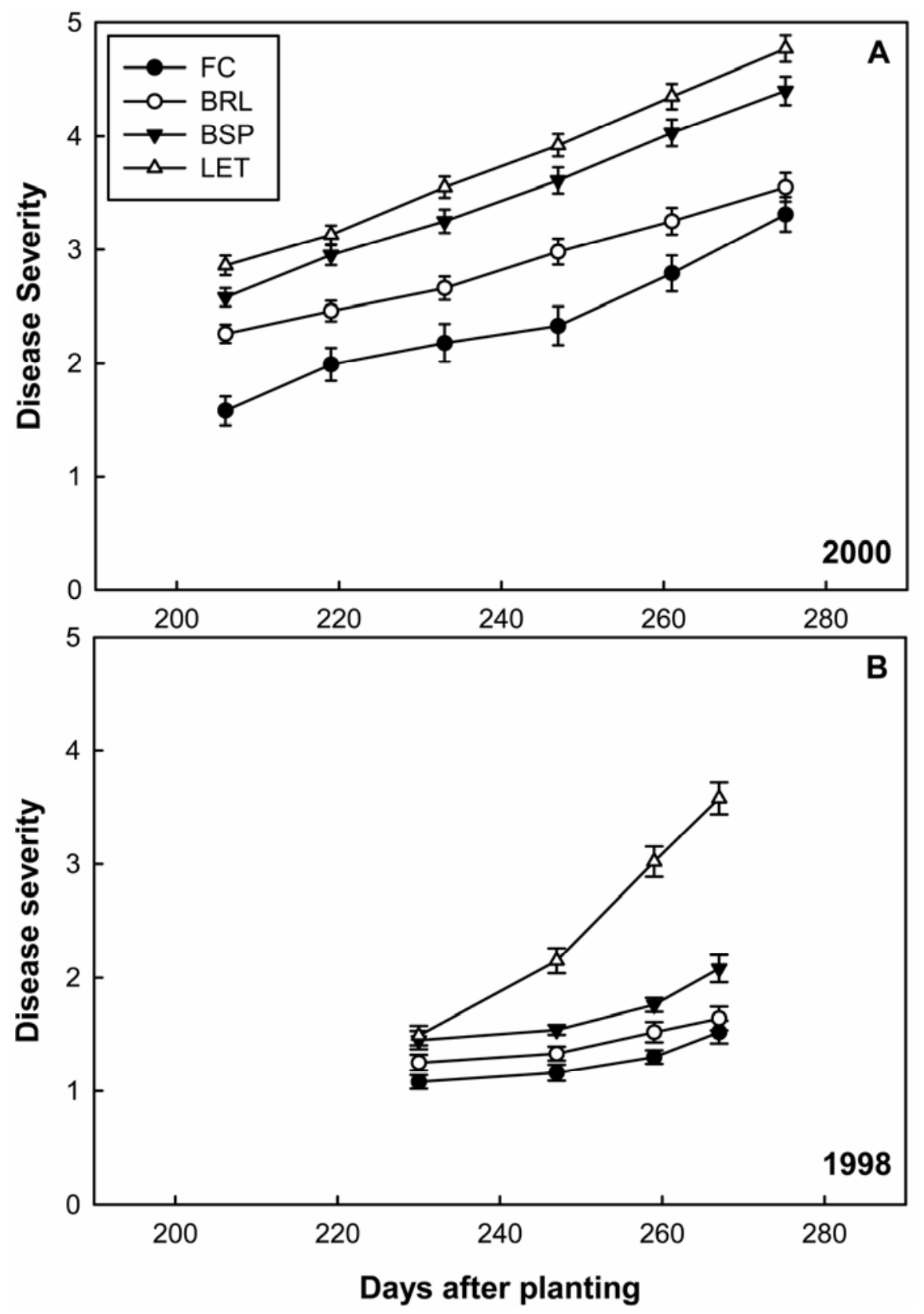

Fig. 3. Effects of crop rotation on strawberry disease severity in A, 2000 and B, 1998 at Watsonville, CA. Abbreviations: $\mathrm{FC}=$ fumigated control, $\mathrm{BRL}=$ broccoli rotation plots, $\mathrm{BSP}=$ Brussels sprouts rotation plots, and LET = lettuce rotation plots. Vertical bars represent the standard error of the mean. Different letters on the bars indicate significant differences among the treatments according to least significant difference at $P \leq 0.05$. wilt severity among the three rotation treatments. Even though the differences in wilt severity between fumigated and broccoli rotation plots were significant through much of the season, final wilt severity was nearly identical between the two treatments (Fig. 3A). Wilt severity in the Brussels sprouts rotation plots was intermediate between broccoli and lettuce rotation plots throughout the season (Fig. 3A). In 2000, the onset of Verticillium wilt occurred 3 weeks later, and the severities were lower relative to 1998 (Fig. 3B). The response of different treatments, however, was nearly identical to 1998 , with the least wilt severity recorded in fumigated plots followed by broccoli, Brussels sprouts, and lettuce (Fig. 3B). Final wilt severity in fumigated plots and plots that had broccoli residue incorporated was nearly identical and not statistically significant from each other (Fig. 3B).

As in the Watsonville site, disease severity in the Salinas site was highest in the lettuce rotation treatment during both 1998 and 2000 (Fig. 4A and B). Because of the inefficient fumigation in 1997, disease severity on strawberry plants in fumigated plots was higher than in plots that had broccoli residue incorporated in 1998. However, there were no significant differences between these two treatments during the 2000 season (Fig. 4A and B). Strawberry plants in the broccoli-rotated plots showed a consistently lower disease severity than in the remaining vegetable rotation plots during all observed dates.

Effects on strawberry fruit yield. Overall strawberry yield was higher in Salinas than in Watsonville (Figs. 5 and 6). The fumigated control treatment produced the highest marketable (data not shown) and total yields at both locations until comparable dates of harvest (Figs. 5 and 6). The experiment at Watsonville was terminated earlier but was continued at the Salinas site; hence, the final yields appear comparable between the two sites (Figs. 5 and 6). Among the vegetable rotation treatments during both seasons (1997-98 and 1999-2000) at both sites, plots that had broccoli residue incorporated produced the highest strawberry yield. In 1998, total strawberry yield was about $22 \%$ less in plots with broccoli rotation relative to the fumigated plots in Watsonville. However, in 2000, fruit yield in fumigated plots was only $12 \%$ higher than in broccoli-rotated plots. Plots with lettuce rotation consistently had the lowest strawberry yield at both sites during both seasons. In Watsonville, Brussels sprouts plots had intermediate strawberry yield in 1998 but lowest yield in 2000 when it was similar to that in lettuce rotation plots. In 2000, the difference in yield between the lettuce and broccoli rotation plots was greater than in 1998 at the Salinas site (Fig. 6). In 1998, there were no yield differences among the vegetable rotation plots; however, in 2000, 
broccoli rotation plots had the highest and lettuce plots had the lowest strawberry yield, with the yield in cauliflower rotation plots being intermediate.

Cost-benefit analysis. Strawberry production under fumigation incurred the highest production costs but also provided the highest returns. Average total cost of production in 1998 and 2000 was estimated to be $\$ 81,000$ per hectare with a net profit of $\$ 10,500$ per hectare (Table 1). In contrast, the cost of strawberry production without fumigation decreased to an estimated $\$ 77,000$ to 79,000 but also led to losses between $\$ 17,000$ and 19,000 depending on the production site (Table 1). Production of strawberry under crop rotation involved giving up the annual strawberry production during the time rotation crops were grown but resulted in net profits because of income from rotation crops and higher strawberry yield. However, the overall profits were reduced by 20 to $30 \%$ a year relative to the production under fumigation. The total cost of producing strawberry following two crops of broccoli was estimated to be nearly $\$ 82,000$ that resulted in a net profit of $\$ 6,800$ to 7,800 per hectare per year, depending on location (Table 1).

\section{DISCUSSION}

This study demonstrated that rotations with broccoli and Brussels sprouts followed by the postharvest incorporation of the respective residues reduced the number of $V$. dahliae microsclerotia in soil that resulted in concomitant reductions in the incidence of Verticillium wilt and increases in fruit yield of strawberry. None of the rotations, however, reduced Verticillium wilt or increased yield as much as fumigation with methyl bromide + chloropicrin. The benefits of rotations were more evident with broccoli than with Brussels sprouts. Although the results with broccoli rotations are consistent with those obtained on cauliflower $(34,43)$, this is the first demonstration of successful rotations with broccoli and Brussels sprouts on a highly Verticillium wilt-sensitive, deep-rooted (compared with other vegetable crops in coastal California), and long-duration crop such as strawberry. Rotations with lettuce increased the numbers of microsclerotia in soil significantly over pre-rotation levels consistent with it being identified as a new host of $V$. dahliae and the strawberry strain being pathogenic on lettuce and vice versa $(3,26,35)$. None of the rotations influenced the overall populations of Pythium spp. in soil, but it was unclear whether specific rotations influenced the species composition of this population. This often was not apparent on strawberry plants because disease caused by Pythium spp. does not have distinct symptoms on this host that enable diagnosis based on visual symptoms alone (root infection can cause stunting and reduction in vigor, but other root pathogens also cause similar symptoms). Adaptation of successful rotations with broccoli entails giving up the annual strawberry production following fumigation during rotation and nearly $30 \%$ of the annual profits on a per hectare basis. While these short-term losses accrue, growers reap the benefits of reducing soil inoculum over the long-term.

As with cauliflower $(34,43)$, the greatest reduction in the number of microsclerotia at the Watsonville site was observed soon after the incorporation of broccoli and Brussels sprouts residues. This was followed by additional reductions in microsclerotia of $V$. dahliae during the sec- ond cycle of broccoli rotation. The numbers of microsclerotia increased marginally in broccoli plots during the subsequent strawberry season but remained lower than in the Brussels sprouts plots. In contrast, at the Salinas site, even with no detectable $V$. dahliae propagules, broccoli rotations increased strawberry yields as evidenced by higher plant health ratings, suggesting that broccoli may suppress pathogens other than $V$. dahliae or result in enhanced growth of strawberry plants. Even though this study focused on Verticillium and Pythium spp., other soilborne pathogens such as $R$. solani, binucleate Rhizoctonia spp., and Cylindrocar-
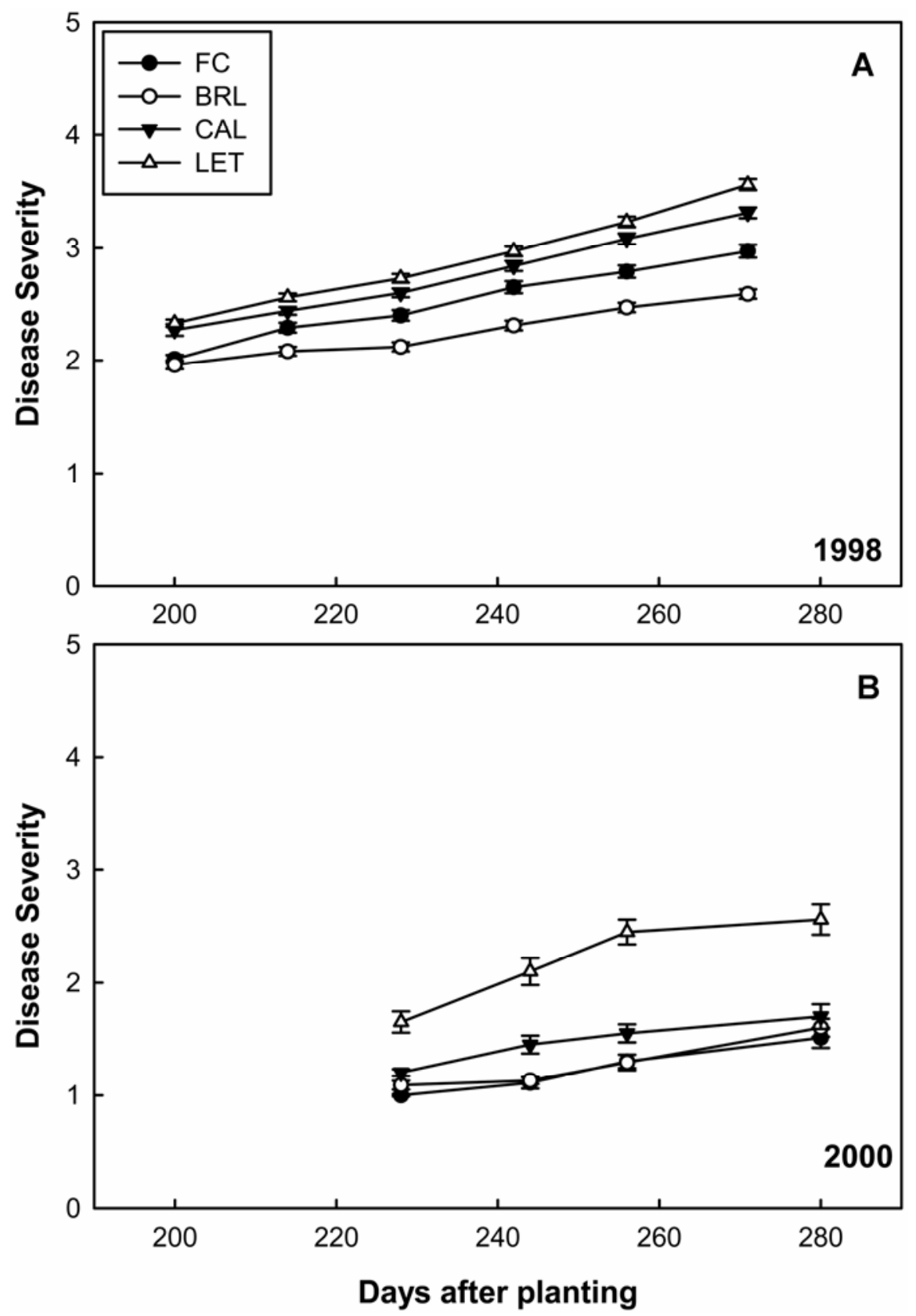

Fig. 4. Effects of crop rotation on strawberry disease severity in A, 1998 and B, 2000 at Salinas, CA. Abbreviations: $\mathrm{FC}=$ fumigated control, $\mathrm{BRL}=$ broccoli rotation plots, $\mathrm{CAL}=$ cauliflower rotation plots, and LET $=$ lettuce rotation plots. Vertical bars represent the standard error of the mean. Different letters on the bars indicate significant differences among the treatments according to least significant difference at $P \leq 0.05$. 
pon spp. also were present at this test site and common in strawberry production systems in California $(20,21)$. One can infer from the results obtained at the $V$. dahliae-free Salinas site that rotations with broccoli have benefits beyond the pathogens tested in the current study.

In contrast to the reductions in $V$. dahliae microsclerotia and wilt on strawberry observed in rotations with broccoli and Brussels sprouts, rotations with lettuce resulted in significant increases in $\mathrm{V}$. dahliae microsclerotia and wilt on strawberry. Prior to 1995 (35), lettuce was not even considered to be a host of $V$. dahliae, but wilt caused by this pathogen currently is a major problem on lettuce in the central coast of California. Recent studies (26) have clearly established that the strawberry and lettuce strains of $V$. dahliae belong to the same phylogenetic group based on the sequence similarities of the intergenic spacer (IGS) region and the combined sequences of the IGS region and the $\beta$ tubulin gene. Furthermore, the two strains were also cross-pathogenic to both hosts. Previous molecular profiling based on random amplified polymorphic DNA analysis also concluded that lettuce and strawberry strains displayed the closest phylogenetic relationship relative to the other host-adapted isolates tested (3). Unlike in most other hosts of $V$. dahliae, microsclerotia develop along the veins of lower, senescing lettuce leaves prior to plant death and result in abundant augmentation of soil inoculum after an infected crop. Therefore, it is not surprising that microsclerotia of $V$. dahliae increased in the soil of lettuce-rotated plots and resulted in higher severity of Verticillium wilt on strawberry and reduced fruit yield compared with other rotations.

Residues of other Brassica spp. have proven effective in reducing several other soilborne pathogens $(2,10,43)$. Keinath (17) reported significant reductions of gummy stem blight of watermelon in soil amended with cabbage residue. Chan and Close (10) demonstrated the control of Aphanomyces root rot from Brassica residue amendments. Brassica spp. are well known for their characteristic sulfurcontaining compounds, known as glucosinolates, and for the disease-suppressive effects of the toxic byproducts derived from the breakdown of these compounds $(10,17,22,28)$. Although this may explain, in part, the successful use of broccoli residues to reduce the number of microsclerotia in soil, other factors also may play an important role in the suppressive effects of
Brassica spp. in general. Shetty et al. (30) found that, despite the apparent lack of foliar symptoms and few root symptoms, broccoli roots still were colonized by $V$. dahliae to the same degree as cauliflower, except when soil microsclerotia levels were high. Under high soil inoculum density, the colonization rate of cauliflower roots was about 1.5 -fold higher compared with broccoli roots. Microsclerotia never developed within broccoli root tissues, even 60 days after decapitating plants at the crown. In addition, there was no apparent inhibition of growth of $V$. dahliae on a medium with broccoli root extracts. This led to the hypothesis that perhaps the reduction in V. dahliae soil populations was caused by the combined effects of broccoli acting as a trap crop to force the germination of microsclerotia and the activation of resident microflora with an ability to degrade lignin-rich broccoli residue in addition to the melanized microsclerotia of $V$. dahliae $(29,30)$. Fungal ligninases have been found to have activity against melanin as well, but microorganisms with melanolytic activity also may be involved $(5,29)$. Data from broccoli-rotated plots demonstrated a 1,000 -fold increase in bacterial and 100-fold increase in actinomycete populations relative to the unamended
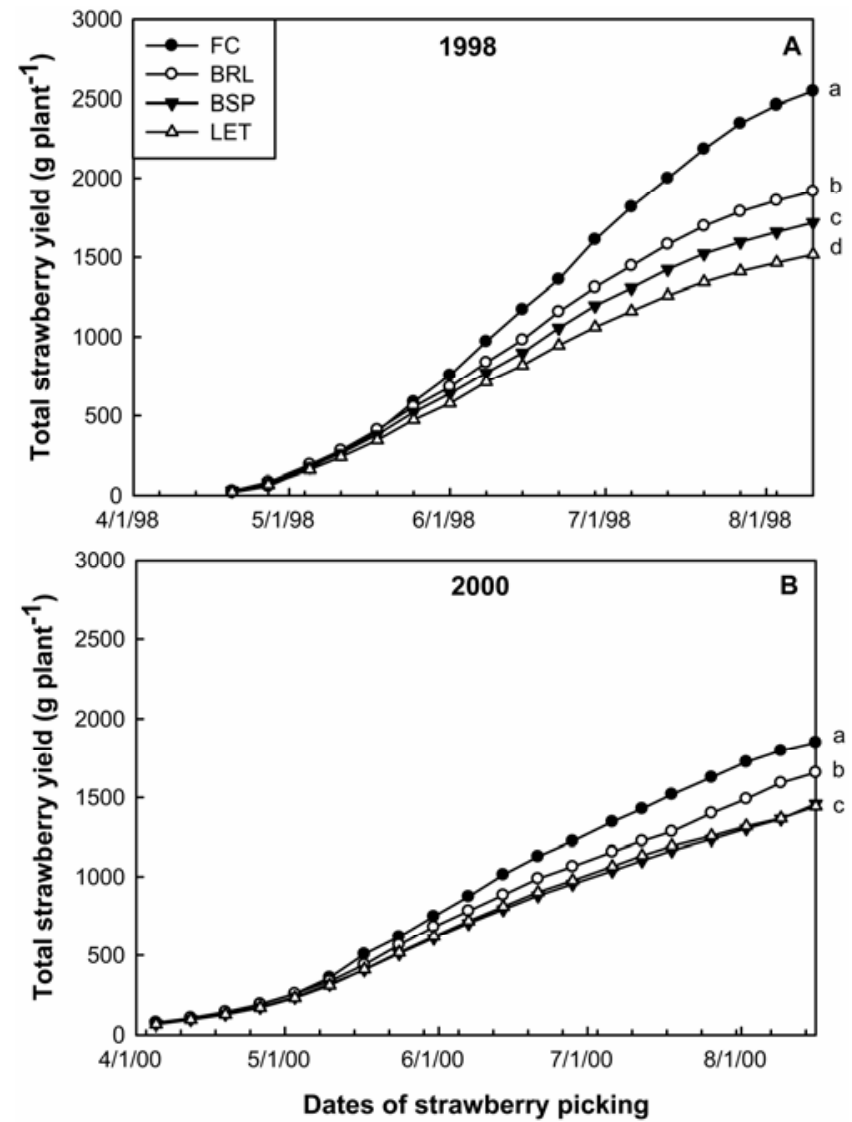

Fig. 5. Effects of crop rotation on strawberry yield in A, 1998 and B, 2000 at Watsonville, CA. Abbreviations: $\mathrm{FC}=$ fumigated control, $\mathrm{BRL}=$ broccoli rotation plots, BSP $=$ Brussels sprouts rotation plots, and LET $=$ lettuce rotation plots. Vertical bars represent the standard error of the mean. Different letters on the lines indicate significant differences among the treatments according to least significant difference at $P \leq 0.05$.
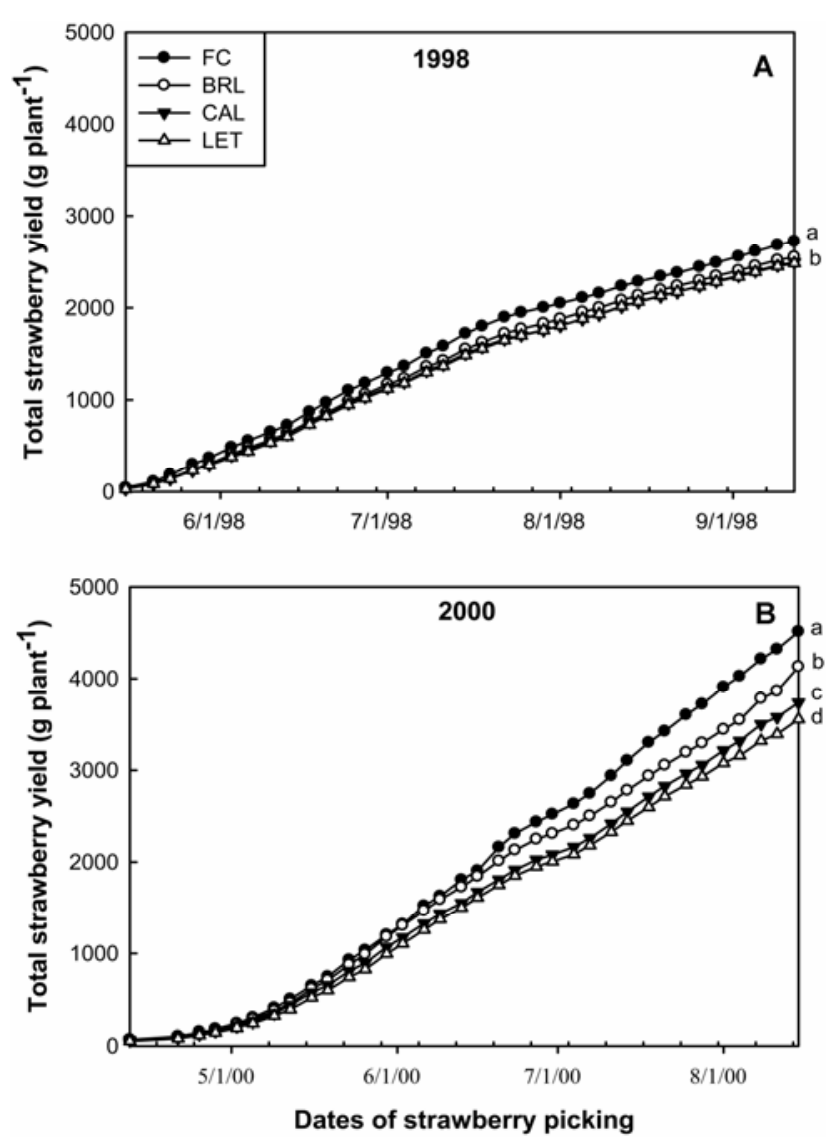

Fig. 6. Effects of crop rotation on strawberry yield severity in A, 1998 and B, 2000 at Salinas, CA. Abbreviations: $\mathrm{FC}=$ fumigated control, $\mathrm{BRL}=$ broccoli rotation plots, $\mathrm{CAL}=$ cauliflower rotation plots, and LET $=$ lettuce rotation plots. Vertical bars represent the standard error of the mean. Different letters on the lines indicate significant differences among the treatments according to least significant difference at $P \leq 0.05$. 
control or cauliflower-rotated plots, suggesting a biological basis for the suppression of $V$. dahliae (K. V. Subbarao, unpublished data). It also is possible that the reduction in $V$. dahliae soil populations is partly due to oxygen depletion, created by the increased microbial activity from the incorporated broccoli residue, or from increases in anaerobic activities induced within the oxygen-depleted environment. Blok et al. (4) determined that broccoliamended or rye grass-amended soils covered with a plastic cover created anaerobic environment sufficient to reduce soil inoculum of $V$. dahliae, Fusarium oxysporum f. sp. asparagi, and $R$. solani. This suppressive effect was lost if the amended soils were not covered (4). In contrast, Subbarao et al. $(34,36)$ found that the effects of incorporated broccoli residue were identical in both open and plasticcovered plots. Perhaps the differences in these two studies can be attributed to the quantity of broccoli residue incorporated (three times greater in Subbarao et al. [34], mimicking what is left over after harvest in a commercial field) and the different field soils. In addition to the effects of glucosinolates on plant pathogens, there may be impacts on the broader soil microbial community, perhaps favoring beneficial organisms.

Other studies also have attributed a biological basis of pathogen suppression from Brassica residues or by other means in naturally suppressive soils. Suppression of take-all in wheat caused by Gaeumannomyces graminis in acidic soils was associated with fungal antagonism by Trichoderma spp. (18,31). Smith et al. (32) failed to observe changes in microbial communities by Brassica tissues when the following crop was wheat. In in vitro studies $(28,32)$, Trichoderma spp. were tolerant to isothiocyanates (product of hydrolysis of glucosinolates) while Aphanomyces, Gaeumanomyces, and Phytophthora spp. were sensitive, suggesting both a direct suppression from the toxicity of isothiocyanates and favoring of antagonism by Trichoderma spp.

The effects of Brassica residues on Pythium propagules in soil have been variable. Stephens et al. (33) reported that mustard tissue incorporation decreased grapevine establishment in soils with high numbers of Pythium propagules. Similarly, Walker and Morey (38) found that, in citrus orchards, the number of Pythium propagules in soil as well as in the root systems were increased by mustard and rapeseed tissue amendments. Although $P$. sulcatum and $P$. violae were highly sensitive to isothiocyanate from Brassica residues, the highly pathogenic $P$. ultimum was tolerant (32). In a recent study, Brassicaceae seed meals (B. napus and Sinapis alba) (M. Mazzola, personal communication) stimulated Pythium populations in certain soils whereas $B$. juncea alone had no effect. In combination with $B$. napus, however, $B$. juncea eliminated the stimulation of resident Pythium spp. typically observed when $B$. napus seed meal was applied alone. Furthermore, elevated populations of Pythium spp. in S. alba or $B$. napus seed meal-treated soils contributed to significant weed suppression. This weed suppression was lost when Ridomil (a.i. R-2-[(2,6-dimethylphenyl)-methoxyacetylamino]-propionic acid methyl ester) was applied to $B$. napus-treated soil and significantly diminished in $S$. alba-treated soils, confirming that the high Pythium numbers contributed to weed suppression (M. Mazzola, personal communication). In the current study, incorporation of broccoli, Brussels sprouts, cauliflower, or lettuce residues did not alter the total $P y$ thium populations in soil. Because the pathogenic Pythium spp. were not quantified separately, the possibility that incorporation of residue from various crops had some effect on this segment of Pythium population could not be ruled out.

The impact of diseases or methods to ameliorate diseases in strawberry is ultimately measured by their effect on yield.

Table 1. Comparisons of production costs and returns of strawberry with or without fumigation and a broccoli-strawberry rotation system during 1997 to $2000^{\mathrm{a}}$

\begin{tabular}{lccc}
\hline Production system & $\begin{array}{c}\text { Cost per } \\
\text { hectare (\$) }\end{array}$ & $\begin{array}{c}\text { Return per } \\
\text { hectare (\$) }\end{array}$ & $\begin{array}{c}\text { Net per year } \\
\text { (\$) }\end{array}$ \\
\hline Strawberry without fumigation & & & \\
$\quad$ Total cost with partial plastic mulch & 79,250 & 59,483 & $-19,767$ \\
Total cost with full-bed plastic mulch & 77,027 & 59,483 & $-17,544$ \\
Strawberry with fumigation & 80,979 & 91,514 & 10,535 \\
Broccoli-strawberry rotation & & & \\
Broccoli (two crops) & 9,386 & 27,294 & $\ldots$ \\
Strawberry with partial plastic mulch & 73,075 & 68,635 & $\ldots$ \\
Strawberry with full-bed plastic mulch & 70,852 & 68,635 & $\ldots$ \\
Total cost under rotation & & & $\ldots$ \\
Strawberry with partial plastic mulch & 82,461 & 95,929 & 6,734 \\
Strawberry with full-bed plastic mulch & 80,238 & 95,929 & 7,846 \\
\hline
\end{tabular}

a All costs and values of crops are based on prices prevalent during 1997 to 2000. Cost of fumigation per hectare was $\$ 3,952$. Strawberry value per tray was an average of $\$ 7.125$ and that of broccoli per carton was $\$ 6.5$. Average yields of strawberry under fumigation were 12,844 trays per hectare and under no fumigation were 8,350 trays per hectare. Average yields of broccoli were 2,100 cartons per hectare each season.
As expected, the fumigated control provided the highest yield and correspondingly the highest profits. Even though none of the rotations equaled the level of pathogen and disease suppression observed in the fumigated control, strawberry yield in broccoli-rotated plots was a close second. The unique cost-benefit analysis employed in this study also supported this conclusion. Despite giving up yearly strawberry cultivation that is practiced in some commercial strawberry fields, rotations with broccoli and, to some extent, Brussels sprouts would be a profitable, environmentally friendly method of managing Verticillium wilt in strawberry that is effective in both conventional and organic strawberry production systems.

\section{ACKNOWLEDGMENTS}

The funding provided by the United States Department of Agriculture-SARE and the California Department of Food and Agriculture-Department of Pesticide Regulation is gratefully acknowledged. The California Strawberry Commission, Coastal Berries, and Golden Field Greenhouses provided material support for this project. We thank F. Westerlund for suggestions throughout this study; S. Yamamoto and P. Kohatsu for managing the strawberry crops; and K. G. Shetty, C. Blackford, T. Price, M. E. Abarca, and M. Orozco for technical assistance.

\section{LITERATURE CITED}

1. Ajwa, H. A., Trout, T., Mueller, S., Wilhelm, S. D., Nelson, S. D., Soppe, R., and Shatley, D. 2002. Application of alternative fumigants through drip irrigation systems. Phytopathology $92: 1349-1355$.

2. Bending, G. D., and Lincoln, S. D. 2000 Inhibition of soil nitrifying bacteria communities and their activities by glucosinolate hydrolysis products. Soil Biol. Biochem. 32:1261-1269.

3. Bhat, R. G., and Subbarao, K. V. 1999. Host range specificity in Verticillium dahliae. Phytopathology 89:1218-1225.

4. Blok, W. J., Lamers, J. G., Termorshuizen, A. J., and Bollen, G. J. 2000. Control of soilborne plant pathogens by incorporating fresh organic amendments followed by tarping. Phytopathology 90:253-259.

5. Butler, M. J., and Day, A. W. 1998. Destruction of fungal melanins by ligninases of Phanerochaete chrysosporium and other white rot fungi. Int. J. Plant Sci. 159:989-995.

6. Butterfield, E. J., and DeVay, J. E. 1977. Reassessment of soil assays for Verticillium dahliae. Phytopathology 67:1073-1078.

7. California Strawberry Commission. 2001. Crop profile of strawberries in California. National Pesticide Assessment Program. Available online.

8. Carpenter, J., Gianessi, L., and Lynch, L. 2000. The Economic Impact of the Scheduled U.S. Phaseout of Methyl Bromide. National Center for Food and Agricultural Policy, Washington, DC.

9. Carter, C. A. 2005. Costs of pesticide regulations for the California strawberry industry: choice of regulatory approach and interactions among regulations. Pages 185-196 in: Annu. Res. Rep. Calif. Strawberry Commission, Watsonville.

10. Chan, M. K. Y., and Close, R. C. 1987 Aphanomyces root rot of peas. 3. Control by the cruciferous amendments. N.Z. J. Agric. Res. 30:225-233.

11. Cook, R. J. 1991. Challenges and rewards of sustainable agriculture research and education. 
Pages 32-76 in: Sustainable Agriculture Research and Education in the Field: A Proceedings. National Research Council, National Academy Press, Washington, DC.

12. Davis, J. R., Huisman, O. C., Westermann, D. T., Hafez, S. L., Everson, D. O., Sorensen, L. H., and Schneider, A. T. 1996. Effects of green manures on Verticillium wilt of potato. Phytopathology 86:444-453.

13. Duniway, J. M. 2002. Non-chemical alternatives used in the USA on horticultural crops. Pages 273-275 in: Proc. Int. Conf. Alternatives to Methyl Bromide. Sevilla, Spain.

14. Duniway, J. M. 2002. Status of chemical alternatives to methyl bromide for pre-plant fumigation of soil. Phytopathology 92:1337-1343.

15. Huisman, O. C., and Ashworth, L. J. 1976. Rotation ineffective as Verticillium control. Calif. Agric. 30:14-15.

16. Kabir, Z., Bhat, R. G., and Subbarao, K. V. 2004. Comparison of media for recovery of Verticillium dahliae from soil. Plant Dis. 88:49-55.

17. Keinath, A. P. 1996. Soil amendment with cabbage residue and crop rotation to reduce gummy stem blight and increase growth and yield of watermelon. Plant Dis. 80:564-570.

18. Kirkegaard, J. M., Sarwar M., Wong, P. T. W., Mead, A., Howe, G., and Newell, M. 2000. Field studies on the biofumigation of take-all by Brassica break crops. Aust. J. Agric. Res. 51:445-456.

19. Martin, F. N. 1992. The Genus Pythium. Pages 39-49 in: Methods for Research on Soil Borne Phytopathogenic Fungi. L. Singleton, ed. American Phytopathological Society, St. Paul, MN.

20. Martin, F. N. 2000. Rhizoctonia spp. recovered from strawberry roots in central coastal California. Phytopathology 90:345-353.

21. Martin, F. N. 2003. Development of alternative strategies for management of soilborne pathogens currently controlled with methyl bromide. Annu. Rev. Phytopathol. 41:325-350.

22. Mayton, H. S., Olivier, C., Vaughn, S. F., and Loria, R. 1996. Correlation of fungicidal activ- ity of Brassica species with allyl isothiocyanate production in macerated leaf tissue. Phytopathology 86:267-271.

23. Mills P. K., and Yang, R. 2003. Prostate cancer risk in California farm workers. J. Occup. Environ. Med. 45:249-258.

24. National Agricultural Statistics Service. 2005. Vegetable 2004 Summary. Agricultural Statistics Board, NASS, U. S. Dep. Agric., Washington DC.

25. Powelson, M. L., and Rowe, R. C. 1993. Biology and management of early dying of potatoes. Annu. Rev. Phytopathol. 31:111-126.

26. Qin, Q-M., Vallad, G. E., Wu, B. M., and Subbarao, K. V. 2006. Phylogenetic analyses of phytopathogenic isolates of Verticillium. Phytopathology 96:582-592.

27. Ristaino, J. B., and Thomas, W. 1997. Agriculture, methyl bromide, and the ozone hole: can we fill the gaps? Plant Dis. 81:964-977.

28. Sarwar, M., Kirkegaard, J. A., Wong, P. T. W., and Desmarchelier, J. M. 1998. Biofumigation of Brassicas. III. In vitro toxicity of isothiocyanates to soil-borne pathogens. Plant Soil 201:103-112.

29. Shetty, K. G., and Subbarao, K. V. 1999. Melanolytic activity of microorganisms and antagonism to Verticillium dahliae. (Abstr.) Phytopathology 89:S72.

30. Shetty, K. G., Subbarao, K. V., Huisman, O. C., and Hubbard, J. C. 2000. Mechanism of broccoli-mediated Verticillium wilt reduction in cauliflower. Phytopathology 90:305-310.

31. Smith, B. J., and Kirkegaard, J. A. 2002. In vitro inhibition of soil microorganisms by 2 phenylethyl isothiocyanate. Plant Pathol. 51:585-593.

32. Smith, B. J., Kirkegaard, J. A., and Howe, G. N. 2004. Impacts of Brassica break-crops on soil biology and yield of following wheat crops. Aust. J. Agric. Res. 55:1-11.

33. Stephens, P. M. 1999. Effects of methyl bromide, metam sodium and the biofumigants Indian mustard and canola on the incidence of soilborne fungal pathogens and growth of grapevine nursery stock. Aust. Plant Pathol. 28:187-196.

34. Subbarao, K. V., and Hubbard, J. C. 1996. Interaction effects of broccoli residue and temperature on Verticillium dahliae microsclerotia in soil and on wilt in cauliflower. Phytopathology 86:1303-1310.

35. Subbarao, K. V., Hubbard, J. C., Greathead, A S., and Spencer, G. A. 1997. Verticillium Wilt. Pages 26-27 in: Compendium of Lettuce Diseases. R. M. Davis, K. V. Subbarao, R. N. Raid, and E. A. Kurtz, eds. American Phytopathological Society Press, St. Paul, MN.

36. Subbarao, K. V., Hubbard, J. C., and Koike, S. T. 1999. Evaluation of broccoli residue incorporation into field soil for Verticillium wilt control in cauliflower. Plant Dis. 83:124-129.

37. United States Department of Agriculture Economic Research Service, 2000. Economic implications of the methyl bromide phaseout. Agric. Inf. Bull. No. 756

38. Walker, G. E., and Morey, B. G. 1999. Effect of Brassica and weed manures on abundance of Tylenchulus semipenetrans and fungi in citrus orchard soil. Aust. J. Exp. Agric. 39:65-72.

39. Wilhelm, S. 1966. Chemical treatments and inoculum potential of soil. Annu. Rev. Phytopathol. 4:53-78.

40. Wilhelm, S. 1998. Verticillium Wilt. Pages 5152 in: Compendium of Strawberry Diseases. J. L. Maas, ed. American Phytopathological Society Press, St. Paul, MN.

41. Wilhelm, S., and Paulus, A. O. 1980. How soil fumigation benefits the California strawberry industries. Plant Dis. 64:264-270.

42. Wilhelm, S., Storkan, R. C., and Sager, J. E. 1961. Verticillium wilt of strawberry controlled by fumigation of soil with chloropicrin and chloropicrin-methyl bromide mixtures Phytopathology 51:744-748.

43. Xiao, C. L., Subbarao, K. V., Schulbach, K. F, and S. T. Koike 1998. Effects of crop rotation and irrigation on Verticillium dahliae microsclerotia in soil and wilt in cauliflower. Phytopathology 88:1046-1055. 